Pediat. Res. 3: 532-537 (1969)

Fibroblasts

$\mathrm{G}_{\mathrm{M} 1}$ gangliosidosis

$\beta$-galactosidase

gangliosides

\title{
$\beta$-Galactosidase in Tissue Culture Derived from Human Skin and Bone Marrow: Enzyme Defect in $\mathrm{G}_{\mathrm{M} 1}$ Gangliosidosis
}

\author{
Howard R. Sloan ${ }^{[34]}$, B. William Uhlendorf, Cectl B.Jacobson \\ and Donald S. Fredriakson \\ Molecular Disease Branch, National Heart Institute, and Laboratory of Viral Immunology, \\ Division of Biologics Standards, Bethesda, Maryland, and Department of Obstetrics and Gynecology, \\ George Washington University School of Medicine, Washington, D.G.
}

Extract

$\beta$-Galactosidase activities were determined in fibroblast preparations derived from the bone marrow and skin of a patient with $\mathrm{G}_{\mathrm{M} 1}$ gangliosidosis and from 11 control subjects. Two $\beta$-galactosidase substrates were employed in these studies: ganglioside $\mathrm{G}_{\mathrm{M} 1}$, labeled with tritium in the terminal galactose by a new procedure, and 0 -nitrophenyl- $\beta$-galactopyranoside. The $\mathrm{G}_{\mathrm{MI}}-\beta$-galactosidase activity in the cells of the patient was reduced 17- to 30-fold compared with the activity in the cells of the control subjects; also, the cells of the patient exhibited an 11- to 30-fold depression in 0 -nitrophenyl- $\beta$-galactosidase activity (ONP- $\beta$-galactosidase). These results demonstrated that fibroblasts cultured from an affected subject might be employed for diagnostic purposes. The $\mathrm{G}_{\mathrm{M} 1-}$ and $o$-nitrophenyl- $\beta$-galactosidase activities of fibroblasts cultured from normal amniotic fluid have also been determined; $o$-nitrophenyl- $\beta$-galactosidase activities ranged from 61 to 153 units/ $/ 10^{6}$ cells and the $\mathrm{G}_{\mathrm{M} 1-}-\beta$-galactosidase activities varied between 45 and 95 units $/ 10^{8}$ cells.

\section{Speculation}

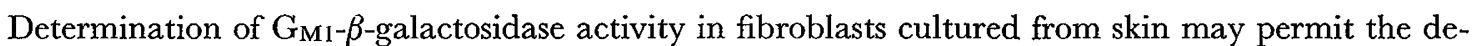
tection of individuals heterozygous for $\mathrm{G}_{\mathrm{M} 1}$ gangliosidosis. The presence of a $\beta$-galactosidase capable of releasing the terminal galactose from ganglioside $\mathrm{G}_{\mathrm{M} 1}$ in fibroblasts derived from amniotic fluid offers a basis for possible intrauterine diagnosis of $\mathrm{G}_{\mathrm{M} 1}$ gangliosidosis.

\section{Introduction}

Generalized gangliosidosis ( $\mathrm{G}_{\mathrm{M} 1}$ gangliosidosis) is a rare inherited metabolic disorder characterized by the accumulation of large quantities of $\mathrm{G}_{\mathrm{M} 1}$ ganglioside, galactosyl-(1 $\rightarrow 3)$-N-acetyl-galactosaminyl-( $\rightarrow 4)$ -
$[(2 \rightarrow 3)$-N-acetylneuraminyl]-galactosyl-(1 $\rightarrow 4)$ glucosyl- $(1 \rightarrow 1)-[2-\mathrm{N}$-acyl]-sphingosine, in the brain and visceral organs $[9,11,22]$. Clinically, the disorder is manifested by progressive neurological deterioration, accumulation of glycolipid in neurons and reticuloendothelial cells, skeletal and facial features similar to 
those seen in Hurler's syndrome, and death by 2 years of age. Derry et al. [3] have proposed that there is a second form of $\mathrm{G}_{\mathrm{M} 1}$ gangliosidosis in which ganglioside $G_{M 1}\left(G_{M 1}\right)$ accumulates only in the brain without osseous defects or visceromegaly.

A deficiency of $o$ - and $p$-nitrophenyl- $\beta$-galactosidase activity has recently been demonstrated in the liver, spleen, kidney, and brain of four patients with $G_{M 1}$ gangliosidosis $[2,12,15]$. In addition, OKADA and O'BRIEN [12] demonstrated depressed levels of $\mathrm{G}_{\mathrm{M} 1-}$ $\beta$-galactosidase activity in tissues from two of these patients. Deficiency in the activity of lysosomal $\beta$ galactosidase, which normally cleaves the terminal galactose from the oligosaccharide moiety of $\mathrm{G}_{\mathrm{M} 1}$, probably accounts for the accumulation of $\mathrm{G}_{\mathrm{M} 1}$ in generalized gangliosidosis.

We have determined the $\beta$-galactosidase activity with $o$-nitrophenyl- $\beta$-D-galactopyranoside (ONPG) as substrate in fibroblast cultures derived from the skin and from bone marrow of a patient with $\mathrm{G}_{\mathrm{M} 1}$ gangliosidosis and in cultures from 11 control subjects. An additional method using tritiated $\mathrm{G}_{\mathrm{M} 1}\left(\mathrm{G}_{\mathrm{M1}}{ }^{-3} \mathrm{H}\right)$ was also developed to assay the enzyme.

\section{Subjects and Methods}

Patient MB (NIH 07-22-86) was 14 months old at the time the biopsies for initiation of cell cultures were obtained; he died at the age of 2 years. The diagnosis of $\mathrm{G}_{\mathrm{MI}}$ gangliosidosis was established by isolating and quantifying the gangliosides from portions of brain and liver $[10,22]$. These tissues contained 1,900 and $108 \mu \mathrm{g}$ of $\mathrm{G}_{\mathrm{M} 1}$ sialic acid/g wet weight, respectively, an increase of 20-50 times the normal $\mathrm{G}_{\mathrm{Ml}}$ content $[3,19,20]$.

Control cells were derived from one normal subject and from patients with diseases other than $G_{M 1}$ gangliosidosis. The control subjects ranged in age from 6 months to 26 years of age. Cultures were initiated from bone marrow aspirates and from 3-mm punch skin biopsies [23]. The growth medium used was Eagle's 'minimum essential medium' containing the nonessential amino acids [5], 10\% fetal bovine serum and neomycin $(50 \mu \mathrm{g} / \mathrm{ml})$. Usually in 3 weeks sufficient outgrowth of fibroblasts from primary explants occurred to permit subcultivation of the cells at 3- to 6-day intervals. The cells used for subcultivation were removed from the glass surface and dispersed with $0.25 \%$ trypsin. As viewed under the light microscope, the cell morphology and growth pattern of the cells from the patient with $\mathrm{G}_{\mathrm{M} 1}$ and those from the control subjects were the same.

Cells used for enzyme assays were grown as monolayer cultures in 32-oz prescription bottles. At the time of harvesting the cells were rinsed with $\mathrm{Ca}^{2+}, \mathrm{Mg}^{2+}$ free Dulbecco's saline solution [4] and removed from the glass by treatment with this solution containing: (in percent) trypsin, 0.05 ; ethylenediaminetetraacetate (EDTA), 0.005; and methylcellulose, 0.2. Cells, 30-60 $\times 10^{6}$, were then suspended in $40 \mathrm{ml}$ of Dulbecco's saline containing $0.1 \%$ methylcellulose, and a $0.5-\mathrm{ml}$ aliquot was removed for counting [28]. The cell suspension was then centrifuged at $600 \times g$; the pellet was resuspended in $10 \mathrm{ml}$ of cold methylcellulose-saline and centrifuged at $600 \times g$. The cell pellet was stored at $-80^{\circ}$ until processed further.

Other cells were suspended in $1 \mathrm{ml}$ of $0.25 \mathrm{M}$ sucrose containing $2.5 \%$ Cutscum (isooctylphenoxypolyoxyethanol) [29] and disrupted by the microtip of a sonifier [30]. The output control selector was set at no. 2 and the output of the microtip was $1.2 \mathrm{amp}$. The cells were sonified at $0^{\circ}$ for two $30-\mathrm{sec}$ periods, interrupted by a 1-min pause. Aliquots of the resulting preparation were assayed immediately or after storage at $-70^{\circ}$. Repeated freezing and thawing did not affect the activity of the various enzymes assayed.

The incubation mixture for the assay of ONP- $\beta$ galactosidase activity contained an aliquot of the fibroblast preparation representing approximately $10^{5}$ cells; $25 \mu$ moles of sodium acetate buffer, $\mathrm{pH} 5.1$; $1.33 \mu$ moles of ONPG; $200 \mu \mathrm{g}$ of Cutscum; and water in a final volume of $0.2 \mathrm{ml}$. After incubation for $90 \mathrm{~min}$ at $37^{\circ}$, the reaction was terminated by the addition of $0.1 \mathrm{ml}$ of human serum albumin $(100 \mathrm{mg} / \mathrm{ml})$ and 0.5 $\mathrm{ml}$ of $4 \%$ trichloroacetic acid. The clear supernatant solution obtained by low speed centrifugation $(500 \times g)$ was pipetted into $0.4 \mathrm{ml}$ of $1 \mathrm{M}$ sodium carbonate. The $o$-nitrophenol concentration was determined by measuring the optical density at $415 \mathrm{~m} \mu$. One unit of ONP- $\beta$-galactosidase activity was defined as the amount of enzyme required to catalyze the hydrolysis of 1 nmole (nanomole) of ONPG/h under the standard conditions.

$\mathrm{G}_{\mathrm{Ml}}$, isolated from the brain of patient $\mathrm{MB}$, was tritiated by oxidation with galactose oxidase followed by reduction with sodium borohydride- ${ }^{3} \mathrm{H}(17)$. The radioactive $\mathrm{G}_{\mathrm{M} 1}$ was purified by column chromatography on Anasil S [13]. The purified $\mathrm{G}_{\mathrm{Ml}^{-}}{ }^{3} \mathrm{H}$ migrated as a single band on thin-layer plates of silica gel $G$ that were developed in either chloroform-methanol$2.5 \mathrm{~N}$ ammonium hydroxide $(60: 35: 8)$ or $n$-propanolwater (7:3) [27]. The labeled ganglioside had the same $R_{F}$ as authentic $\mathrm{G}_{\mathrm{Ml}}$. Incubation of the $\mathrm{G}_{\mathrm{M} 11^{-}}{ }^{3} \mathrm{H}$ with rat brain $\beta$-galactosidase [7] demonstrated that more than $90 \%$ of the tritium was in the terminal galactose moiety.

$\mathrm{G}_{\mathrm{M} 1}{ }^{3} \mathrm{H}$ was used as a specific substrate for the deter-

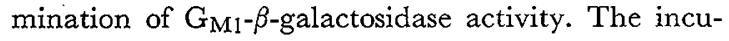
bation mixture contained an aliquot of the fibroblast 
Table I. $\beta$-Galactosidase activities in fibroblasts cultured from bone marrow and skin biopsies of control subjects and of a patient with $\mathrm{G}_{\mathrm{M} 1}$ gangliosidosis

\begin{tabular}{|c|c|c|c|c|c|c|c|}
\hline \multirow[t]{2}{*}{ Patients } & \multirow[t]{2}{*}{ Age } & \multirow[t]{2}{*}{$\begin{array}{l}\text { Type of } \\
\text { biopsy }\end{array}$} & \multirow[t]{2}{*}{ Diagnosis } & \multicolumn{2}{|c|}{$\begin{array}{c}\beta \text {-Galactosidase } \\
\text { activity with } \\
\text { substrate }\end{array}$} & \multicolumn{2}{|c|}{$\begin{array}{l}\text { Activity of other } \\
\text { lysosomal } \\
\text { enzymes }\end{array}$} \\
\hline & & & & $\overline{\mathrm{ONPG}^{1}}$ & $\begin{array}{l}\mathrm{G}_{\mathrm{Ml}^{-}} \\
{ }^{3} \mathrm{H}^{2}\end{array}$ & $\begin{array}{c}\text { Acid } \\
\text { phos- } \\
\text { phatase }^{3}\end{array}$ & $\begin{array}{c}\beta-N- \\
\text { acetyl- } \\
\text { galactos- } \\
\text { amini- } \\
\text { dase }^{4}\end{array}$ \\
\hline & & & Control cultures & & & & \\
\hline $\mathrm{CG}$ & 8 years & Marrow & Inclusion body encephalitis & 67 & 65 & 493 & 33 \\
\hline AS & 4 years & Marrow & Niemann-Pick disease & 79 & 84 & 499 & 30 \\
\hline $\mathrm{MM}$ & 2 years & Marrow & Niemann-Pick disease & 95 & & 572 & 37 \\
\hline $\mathrm{JT}$ & 18 months & Marrow & Undifferentiated lipidosis & & 56 & & \\
\hline VW & 15 months & Marrow & Mental retardation & 99 & 91 & 373 & 30 \\
\hline $\mathrm{JF}$ & 6 months & Marrow & Niemann-Pick disease & 111 & & 327 & 30 \\
\hline OS & 59 years & Skin & Rheumatic heart disease & 86 & & & \\
\hline $\mathrm{PO}$ & 22 years & Skin & Niemann-Pick disease & 59 & & 395 & 22 \\
\hline PU & 21 years & Skin & Normal volunteer & 92 & 75 & 401 & 31 \\
\hline RH & 5 years & Skin & Vogt-Spielmeyer disease & 63 & & & \\
\hline PW & 18 months & Skin & Niemann-Pick disease & 105 & 81 & & \\
\hline VW & 15 months & Skin & Mental retardation & 79 & 52 & 328 & 25 \\
\hline & & & Patient's cultures & & & & \\
\hline $\mathrm{MB}$ & 18 months & Marrow & $\mathrm{G}_{\mathrm{M} 1}$ gangliosidosis & 6 & $<3$ & 464 & 43 \\
\hline $\mathrm{MB}$ & 18 months & Skin & $\mathrm{G}_{\mathrm{M} 1}$ gangliosidosis & 3 & $<3$ & 398 & 39 \\
\hline
\end{tabular}

1 Activity expressed as nmoles 0 -nitrophenyl- $\beta$-D-galactopyranoside hydrolyzed $/ 10^{6}$ cells $/ \mathrm{h}$.

${ }^{2}$ Activity expressed as nmoles galactose- ${ }^{3} \mathrm{H}$ released $/ 10^{8} \mathrm{cells} / \mathrm{h}$.

${ }^{3}$ Activity expressed as nmoles $p$-nitrophenylphosphate hydrolyzed $/ 10^{6} \mathrm{cells} / \mathrm{h}$.

${ }^{4}$ Activity expressed as nmoles $p$-nitrophenyl- $\beta$-N-acetyl-galactosaminide hydrolyzed $/ 10^{6} \mathrm{cells} / \mathrm{h}$.

preparation representing approximately $10^{5}$ cells; 25 $\mu$ moles of sodium acetate buffer, $\mathrm{pH} 5.1 ; 2.5$ nmoles of $\mathrm{G}_{\mathrm{MI}^{-}}{ }^{3} \mathrm{H}(17 \mathrm{mCi} / \mathrm{mmole}) ; 1 \mu$ mole sodium deoxytaurocholate [29]; $200 \mu \mathrm{g}$ of Cutscum; and water in a final volume of $0.2 \mathrm{ml}$.

After incubation for $90 \mathrm{~min}$ at $37^{\circ}$, the reaction was terminated by heating for $3 \mathrm{~min}$ at $100^{\circ}$. The galactose liberated from $G_{M 1}$ was separated from excess $G_{M 1}$ and the other reaction product, ganglioside $\mathrm{G}_{\mathrm{M} 1}$ [31], by thin-layer chromatography. Chromatography was performed on thin-layer plates of silica gel $\mathrm{G}$ with chloroform-methanol-2.5 $\mathrm{N}$ ammonium hydroxide $(60: 35: 8)$ as solvent. The area corresponding to galactose was scraped and counted in a liquid scintillation counter with a Triton-toluene counting fluid [1]. One unit of $\mathrm{G}_{\mathrm{M1}}-\beta$-galactosidase activity was defined as the amount required to catalyze the release of $1 \mathrm{nmole}$ galactose $-{ }^{3} \mathrm{H} / \mathrm{h}$ under the standard conditions. The galactosidase activity as measured with ONPG or $\mathrm{G}_{\mathrm{M1}}{ }^{3} \mathrm{H}$ was linear with respect to time and enzyme concentration over the range examined.

Acid phosphatase and $\beta$-N-acetyl-galactosaminidase activities of the tissue culture preparations were also determined $[8,18]$. The substrates, $p$-nitrophenylphosphate and $p$-nitrophenyl- $\beta$-N-acetylgalactosaminide, were obtained commercially [32].

\section{Results and Discussion}

A deficiency of both ONP- $\beta$-galactosidase and ganglioside $\mathrm{G}_{\mathrm{M1}}-\beta$-galactosidase activities was found in fibroblast cultures derived from skin and from bone marrow biopsies of patient MB (table I). The ONP- $\beta$-galactosidase activity in his cultures was $2.5-10 \%$ of the activity in the cultures from control subjects. With $\mathrm{GM}_{\mathrm{M}^{-}}{ }^{3} \mathrm{H}$ 
as substrate, cell cultures of patient MB demonstrated no activity by an assay capable of detecting 3 units of activity per $10^{8}$ cells; $\mathrm{G}_{\mathrm{M} 1}-\beta$-galactosidase activity was less than $6 \%$ of that in the least active control culture. The deficiency of activity against either galactoside was specific for $\mathrm{G}_{\mathrm{M} 1}$ gangliosidosis (table $\mathrm{I}$ ).

The activities of two other lysosomal hydrolases, acid phosphatase and $\beta$ - $\mathrm{N}$-acetylgalactosaminidase, were determined to demonstrate the metabolic competency of the cells from patient MB. The activities of these enzymes were not depressed (table I). Aliquots of a single sonically disrupted cell preparation were used for multiple $\beta$-galactosidase and 'control' enzyme assays. In most cases the values in table I are the means of values from two or three assays. In three subcultures of skin and two of the bone marrow, cells of patient $\mathrm{MB}$ exhibited low levels of ONP- and $\mathrm{G}_{\mathrm{M} 1}-\beta$-galactosidase activity.

The results of assays for ONP- and $\mathrm{G}_{\mathrm{M} 1}-\beta$-galactosidase activities in control cells with and without admixture of cells from the patient are shown in table II. Cells from the patient did not inhibit ONP- $\beta$-galactosidase activity; however, there appeared to be a decrease in the $\mathrm{G}_{\mathrm{M1}}-\beta$-galactosidase activity of the control cells in the presence of cells from patient MB. This depressed activity was eliminated by tripling the concentration of $\mathrm{G}_{\mathrm{Ml}^{-}}{ }^{3} \mathrm{H}$ in the incubation mixtures. These experiments indicate that the lower $\beta$-galactosidase activities in the mixtures probably resulted from

Table II. $\beta$-Galactosidase activity in mixtures of cells from control subjects and patient $\mathrm{MB}$

\begin{tabular}{|c|c|c|c|}
\hline \multirow{2}{*}{$\begin{array}{l}\text { Control } \\
\text { subjects }\end{array}$} & \multirow{2}{*}{$\begin{array}{c}\text { Type of } \\
\text { cell }\end{array}$} & \multicolumn{2}{|c|}{ Enzyme activity in cells from } \\
\hline & & $\overline{\text { Control alone }}$ & Control $+\mathrm{MB}^{1}$ \\
\hline \multicolumn{4}{|c|}{ ONP- $\beta$-galactosidase ${ }^{2}$} \\
\hline $\mathrm{PO}$ & Skin & 63 & 59 \\
\hline PU & Skin & 81 & 78 \\
\hline AS & Bone marrow & 80 & 83 \\
\hline \multicolumn{4}{|c|}{$\mathrm{G}_{\mathrm{M} 1}-\beta$-galactosidase ${ }^{3}$} \\
\hline AS & Bone marrow & 80 & 71 \\
\hline VW & Bone marrow & 95 & 78 \\
\hline VW & Skin & 57 & 46 \\
\hline
\end{tabular}

1 For each incubation $2-4 \times 10^{5}$ control cells were used; in the mixtures $5 \times 10^{5}$ cells from patient $\mathrm{MB}$ were added.

${ }^{2}$ Activities expressed as nmoles ONPG hydrolyzed/106 control cells/h.

${ }^{3}$ Activities expressed as nmoles galactose- ${ }^{3} \mathrm{H}$ released/ $10^{8}$ control cells/h. dilution of the labeled substrate by endogenous $G_{M 1}$ and not from the presence of an inhibitor in the patient's cells.

The marked difference between the ONP- and $\mathrm{G}_{\mathrm{M1}}-\beta$-galactosidase activities in the cells of the control subjects was probably the result of the different solubility characteristics of the two substrates. ONPG is water soluble and, therefore, probably more available to the enzyme than $G_{M 1}$, which presumably was present in micellar form. Further metabolism of the galactose liberated from $\mathrm{G}_{\mathrm{M} 1}$ would also result in a lower apparent $\mathrm{G}_{\mathrm{M} 1}-\beta$-galactosidase activity. The latter possibility is probably of minor importance, however, since more than $90 \%$ of the $\mathrm{G}_{\mathrm{M} 1}$ could be recovered following incubation.

We have also cultured a number of cell lines from the fetal cells present in amniotic fluids, obtained by transabdominal amniocentesis or at therapeutic abortion after $12-20$ weeks of gestation. ONP- $\beta$-galactosidase and $\mathrm{G}_{\mathrm{M} 1}-\beta$-galactosidase activities were assayed in four of these lines. The ONP- $\beta$-galactosidase activities ranged from 61 to 153 units $/ 10^{6}$ cells; the $\mathrm{G}_{\mathrm{M1}}-\beta$ galactosidase activities varied between 45 and 95 units $/ 10^{8}$ cells [24]. Thus, cultures derived from amniotic fluid may make possible the detection of $\mathrm{G}_{\mathrm{Ml}}$ gangliosidosis in the developing fetus as early as week 22 of gestation.

Sodium borohydride $-{ }^{3} \mathrm{H}$, with a specific radioactivity of $400 \mathrm{mCi} / \mathrm{mmole}$, was used in the preparation of the $\mathrm{G}_{\mathrm{MI}^{-}}{ }^{3} \mathrm{H}$, and yielded a labeled substrate that permitted the determination of the $\mathrm{G}_{\mathrm{M1}}-\beta$-galactosidase activity in $10^{5}$ fibroblasts. Sodium borohydride- ${ }^{3} \mathrm{H}$ is now available with a specific radioactivity of $6 \mathrm{Ci} / \mathrm{mmole}$. If this reagent was employed, a 15-fold increase in the specific radioactivity of $\mathrm{G}_{\mathrm{M1}}{ }^{3} \mathrm{H}$ could be obtained. Use of this substrate and prolonged incubation of the assay might permit the determination of the $\mathrm{G}_{M 1}-\beta$ galactosidase activity in cultured cells as early as 2 weeks after the amniotic fluid was obtained.

After this work was completed, PINSKy et al. [14] reported depressed levels of ONP- $\beta$-galactosidase activity in cultured fibroblasts of a patient in which $\mathrm{G}_{\mathrm{Ml}}$ accumulated only in the brain.

'Generalized' and 'cerebral' $\mathrm{G}_{\mathrm{M} 1}$ gangliosidosis may represent two manifestations of homozygosity for the same defective gene. The amounts of visceral mucopolysaccharides and visceral glycolipids are two differences in the chemical pathology of these two forms of the disorder [21]. It seems possible that these two forms of $\mathrm{G}_{\mathrm{M} 1}$ gangliosidosis may actually result from two different mutations at the $\beta$-galactosidase locus.

Compared with the normal enzyme, the mutant enzymes might possess different relative affinities for $\mathrm{G}_{\mathrm{M} 1}$ and mucopolysaccharides. Alternatively, one mutation might lead to a more severe deficiency of 
enzymatic activity and, therefore, to a more generalized accumulation of $G_{M 1}$. The ready accessibility of this enzymatic activity in cultured fibroblasts may assist in the further assessment of these two possibilities. It is also entirely possible that enzymatic analysis of cultured fibroblasts may permit detection of the heterozygous state in $\mathrm{G}_{\mathrm{M} 1}$ gangliosidosis.

\section{References and Notes}

1. Benson, R.H.: Limitations of tritium measurements by liquid scintillation counting of emulsions. Analyt. Chem. 38: 1353 (1966).

2. Dagremont, G. and Kint, J.A.: $\mathrm{G}_{\mathrm{M}_{1}}$ ganglioside accumulation and $\beta$-galactosidase deficiency in a

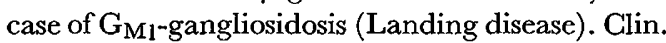
chim. Acta 21: 421 (1968).

3. Derry, D.M.; Fawcett, J.S.; Andermann, F. and WolfE, L. S. : Late infantile systemic lipidosis. Neurology, Minneap. 18: 340 (1968).

4. Dulbecco, R. and Vogr, M.: Plaque formation and isolation of pure lines with poliomyelitis viruses. J.exp. Med. 99: 167 (1954).

5. EAGLE, H. : Amino acid metabolism in mammalian cell cultures. Science 130: 432 (1959).

6. FrohweIN, Y.Z. and GATT, S.: Isolation of $\beta-\mathrm{N}$ acetylhexosaminidase, $\beta$-N-acetylglucosaminidase, and $\beta-\mathrm{N}$-acetylgalactosaminidase from calf brain. Biochemistry 6: 2775 (1967).

7. Gatr, S.: Enzymatic hydrolysis of sphingolipids. V. Hydrolysis of monosialoganglioside and hexosylceramides by rat brain $\beta$-galactosidase. Biochim. biophys. Acta 137: 192 (1967).

8. GATT, S. and Rapport, M.M.: Isolation of $\beta$ galactosidase and $\beta$-glucosidase from brain. Biochim. biophys. Acta 113: 567 (1966).

9. Gonatas, N.K. and Gonatas, J.: Ultrastructural and biochemical observations on a case of systemic late infantile lipidosis and its relationship to TaySachs disease and gargoylism. J. Neuropath. exp. Neurol. 24: 318 (1965).

10. Kanfer, J.N.; Blacklow, R. S. ; Warren, L. and BRADY, R.O.: The enzymatic synthesis of gangliosides. I. The incorporation of labeled N-acetylneuraminic acid into monosialoganglioside. Biochem. Biophys. Res. Commun. 14: 287 (1964).

11. O'Brien, J.S.; Stern, M.B.; Landing, B.H.; O'Brien, J.K. and Donnell, G. N.: Generalized gangliosidosis. Amer. J. Dis. Child. 109: 338 (1965).

12. OkadA, S. and O'Brien, J. S. : Generalized gangliosidosis: Beta-galactosidase deficiency. Science 160: 1002 (1968).
13. Penick, R.J.; Meisler, M.H. and MaCluer, R.H.: Thin-layer chromatographic studies of human brain gangliosides. Biochim. biophys. Acta 116: 279 (1966).

14. Pinsky, L.; Gallahan, J.W. and Wolfe, L.S.: Fucosidosis? Lancet $i i$ : 1080 (1968).

15. SAcrez, R.; Juif, J. G.; Grgonnet, J. M. et GruNER, J.E.: La maladie de Landing ou idiotie amaurotique infantile précoce avec gangliosidose généralisée de type $\mathrm{G}_{\mathrm{M} 1}$. Pédiatrie 22: 143 (1967).

16. Sellinger, O.Y.; Beaufay, H.; Jacques, P.; Doyen, A. and DeDuve, C.: Tissue fractionation studies. 15. Intracellular distribution and properties of $\beta$-N-acetylglucosaminidase and $\beta$-galactosidase in rat liver. Biochem. J. 74: 450 (1960).

17. Sloan, H.R. and Temel, S.: The preparation of large quantities of pure tritium-labeled $\mathrm{G}_{\mathrm{Ml}}$-ganglioside. (Submitted for publication.)

18. Sloan, H.R.; UhlendoRf, B.W.; Kanfer, J.N.; Brady, R.O. and Fredrickson, D.S.: Deficiency of sphingomyelin-cleaving enzyme activity in tissue cultures derived from patients with Niemann-Pick disease. Biochem. Biophys. Res. Commun. 34: 582 (1969).

19. Suzukr, K.: Cerebral $\mathrm{G}_{\mathrm{Ml}}$-gangliosidosis: Chemical pathology of visceral organs. Science 159: 1471 (1968).

20. Suzukr, K.; Suzuki, K. and Chen, G. C.: Morphological, histochemical and biochemical studies on a case of systemic late infantile lipidosis (generalized gangliosidosis). J. Neuropath. exp. Neurol. 27: 15 (1968).

21. Suzukr, K. ; Suzuki, K. and Kamoshita, S. : Chem-

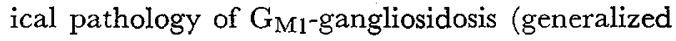
gangliosidosis). J.Neuropath. exp. Neurol. 28: 25 (1969).

22. Svennerholm, L.: The gangliosides. J. Lipid Res. 5: 145 (1964).

23. Uhlendorf, B.W.; Holtz, A.I.; Mock, M.B. and FREDRIGKSON, D. S.: Persistence of a metabolic defect in tissue cultures derived from patients with Niemann-Pick disease; in: S.M.Aronson and B.W.Volk: Inborn disorders of sphingolipid metabolism, p. 443 (Pergamon Press, New York 1966).

24. UhLeNDORF, B.W.; SloAn, H.R.; JACOBSON, C.B. and FREDRICKSON, D.S. (In preparation.)

25. Wattiaux, R.; Wibo, M. and Baudhuin, P.: Influence of injection of triton WR-1339 on properties of rat-liver lysosomes; in: A.V.S. DE REUCK and M.P. Gameron: Ciba Found. Symp. Lysosomes, p. 176 (Little, Brown, Boston 1963).

26. Weinreb, N.J.; Brady, R.O. and TAppel, A. L.: The lysosomal localization of sphingolipid hydrolases. Biochim. biophys. Acta 159: 141 (1968). 
27. Wherrett, J.R. and Cummings, J.N.: Detection and resolution of gangliosides in lipid extracts by thin-layer chromatography. Biochem.J. 86: 378 (1963).

28. Coulter Electronics Inc., Hialeah, Fla.

29. Cutscum was purchased from Fisher Scientific Company, Fair Lawn, N.J., USA; sodium deoxytaurocholate was obtained from Maybridge Research Chemicals, Tintagel, North Cornwall, UK. 30. Branson Instruments Inc., Stamford, Conn.

31. The structure of $\mathrm{G}_{\mathrm{M} 2}$ is identical to that of $\mathrm{G}_{\mathrm{M} 1}$ minus the terminal galactose.

32. Mann Research Laboratories, 136 Liberty Street, New York, N.Y.

33. We thank Dr. Lya Singer, Children's Hospital of Washington, D.C., for providing the autopsy material on the patient. We thank Mrs. BARBARA Davis, Miss Seniye Temel, and Mrs. Kristin Hinds for technical assistance.

34. Requests for reprints should be addressed to: HoWARD R.SLOAN, M.D., Ph.D., National Heart Institute, Bethesda, Maryland 20014 (USA). 